\title{
The Simultaneous Impact of Supplier and Customer Involvement on New Product Performance
}

\author{
Hongyi Sun', Hon Keung Yau², Eric Kwok Ming Suen³
}

\begin{abstract}
The recall rates of various products these years have triggered a new round of interests in the impacts of supplier involvement (SI) and customer involvement (Cl) on new product performance (NPP). However, existing literature looks at either $\mathrm{SI}$ or $\mathrm{Cl}$ but not both. Most supply chain management papers focus on SI and NPP while research in marketing field focuses on $\mathrm{Cl}$ and NPP. Additionally, the NPP has not been elaborated into detail dimensions in these previous studies. This research investigates the impact of both $\mathrm{Sl}$ and $\mathrm{Cl}$ on the three dimensions of NPP, namely new product quality and reliability, time to market and product innovativeness. The research was based on the data from over 600 manufacturers in 21 countries. Structural equation modeling (SEM) is used to test the simultaneous impact of $\mathrm{Sl}$ and $\mathrm{Cl}$ on NPP. The results show that SI influences all the three dimensions of NPP while $\mathrm{Cl}$ influences quality and reliability. The research also reveals that companies pay more attention to $\mathrm{Cl}$ than $\mathrm{Sl}$. It seems that more efforts in both academic and practical fields are needed to enhance SI in relation to NPD. The research suggests that both $\mathrm{SI}$ and $\mathrm{Cl}$ should be implemented in new product development process. It is not a two-party issue but a three-party-issue.
\end{abstract}

Keywords: supplier involvement; customer involvement; new product performance; quality and reliability; time to market; product innovativeness.

\footnotetext{
' Associate Professor, City University of Hong Kong, Department of Manufacturing Engineering and Engineering Management. City University of Hong Kong, 83 Tat Chee Avenue, Kowloon Tong, Kowloon, Hong Kong. Tel. (852) 34429587. Email: mehsun@cityu.edu.hk

2 Instructor, City University of Hong Kong, Department of Manufacturing Engineering and Engineering Management. City University of Hong Kong, 83 Tat Chee Avenue, Kowloon Tong, Kowloon, Hong Kong. Tel. (852) 34426158. Email: honkyau@cityu.edu.hk

${ }^{3}$ Research assistant, City University of Hong Kong, Department of Manufacturing Engineering and Engineering Management. City University of Hong Kong, 83 Tat Chee Avenue, Kowloon Tong, Kowloon, Hong Kong. Tel. (852) 98010436. Email: suenkwokming@gmail.com
} 


\section{Introduction}

New product performance (NPP) is essential to manufacturing companies because it can provide potential implication in company's growth and success (MolinaCastillo \& Munuera-Alemán, 2009b). NPP can help firms select a new product launch strategy decisions (Chiu et al., 2006), lead to new product market success (Millson and Wilemon, 2006), and improve the financial performance and firm value (Pauwels et al., 2004). Factors influencing NPP are various along the process of new product development (NPD). Among others, supplier involvement (SI) and customer involvement $(\mathrm{Cl})$ start to attract more attention in both NPD and supply chain management (SCM) fields. However, there are two concerns in the research related to this topic. On the one hand, researchers in supply chain management investigate $\mathrm{SI}$ and NPD while researchers in marketing and business look into $\mathrm{Cl}$ and NPD. Nearly all previous research either investigates $\mathrm{SI}$ or $\mathrm{Cl}$ in NPD process, but ignores the simultaneous impact of $\mathrm{SI}$ and $\mathrm{Cl}$. There is only one reference (Chien and Chen, 2010) covering both $\mathrm{SI}$ and $\mathrm{Cl}$ about NPD in financial industry. No such reference on manufacturing industry has been ever found. Suppliers and customers are up and down streams of the same supply and value chain. If any of the both is ignored, the whole process of NPD and operations is not complete.

On the other hand, although a great number of authors (e.g. Frohlich and Westbrook 200I, Rosenzweig et al., 2003, Vachon and Klassen 2006, Swink et al., 2007) revealed the positive relationship between $\mathrm{SCl}$ and organisational performance, the impact of $\mathrm{SCl}$ on performance is far from a fact. Zailani and Rajagopal (2005) propose that little is known about the connections between supplier and customer integration and improved operations performance. Power (2005) concludes the apparent contradiction between promised benefits and limited evidence of extensive implementation. So as to the impact of SI on NPP, the findings are paradoxical. Conceptual claims are mostly positive, but empirical findings are mixed (De Meyer and Van Hooland 1990, Hartley et al., 1997a). In fact, Ittner and Larcker (1997) found that supplier involvement actually hampered NPD project performance by lengthening product development lead times. Thus, Fabbe-Costes and Jahre (2008) in their review caveat that evidence cannot be taken for granted and call for more research on the impact of $\mathrm{SCl}$ on performance.

In summary, the following questions about supply chain integration and its influence on performance are remaining unanswered:

I) To what extent will $\mathrm{SI}$ and $\mathrm{Cl}$ influence NPP?

2) What dimensions of NPP will be influenced by SI and $\mathrm{Cl}$ ?

3) To what extent did companies implement SI and CI?

This paper aims to answer the above questions by an empirical research that investigates the impact of both $\mathrm{SI}$ and $\mathrm{Cl}$ on three dimensions of NPP. Structural equation modeling will be used to test the simultaneous impact of SI and $\mathrm{Cl}$ on NPP. The result will fill in the gap in NPD and SCM research on the simultaneous impact of supplier and customer involvement in NPD in manufacturing industry.

\section{Literature Review and Hypothesis \\ Formulation}

\section{New Product Performance (NPP)}

In previous studies, three key indicators were accepted to measure the performance of new product development. They are quality (Hsu et al., 2009; Petersen et al., 2005; Dostaler, 2010) and reliability (Petersen et al., 2005; Corallo et al., 2009; Dostaler, 2010), time to market (Stalk and Hout, 1990; Griffin, 1993; Bonaccorsi and Lipparini, 1994; Langerak et al., 2004; Talke, 2007) and product innovativeness (Montoya-Weiss and Calantone, 1994; Sandvik and Sandvik, 2003; Talke, 2007; Lee, 2008; MolinaCastillo \& Munuera-Alemán, 2009a; 2009b). In this study, those three indicators were used to measure the NPP.

New product development (NPD) is about to become a focal point of competition, leading to higher product quality (Bonaccorsi and Lipparini, 1994). Therefore, quality has been considered as a key indicator of new product performance (Dostaler, 20l0). Evidences show that successful integration of partners can improve the quality of new product design (Petersen et al., 2005; Dostaler, 2010). Besides, reliability is another key indicator of new product performance as the internal failure rate is considered as a particularly appropriate measure of the performance of the development process (Dostaler, 2010). 
All products, especially superior/complex one, should meet reliability standards relative to specifications (García et al., 2008; Corallo et al., 2009). Involvement of supplier can improve the reliability of new product design (Petersen et al., 2005).

As global competitive pressure increases, product life cycles reduce and many manufacturing companies try to shorten their product development cycles (Griffin, 1993; Bonaccorsi and Lipparini, 1994) and move new technology and products from product concept to marketplace in a faster pace (Bonaccorsi and Lipparini, 1994). Therefore, time to market has been identified as a key success factor in NPD (Stalk and Hout, 1990). According to Bonaccorsi and Lipparini (1994), time to market can be reduced by concurrent engineering, earlier identification of technical problems, reduced suppliers' process engineering time, and acquisition of suppliers' production capacity.

New product innovativeness is generally considered as an important indicator of new product performance (MolinaCastillo \& Munuera-Alemán, 2009a; 2009b). A firm's ability to employ new and successful product innovations is an important competitive weapon (Sandvik and Sandvik, 2003). Various definitions of product innovativeness in product development have been used in previous studies. Firstly, product innovativeness refers to the firm's use of products that are new to the firm and/or new to the market (Booz, Allen \& Hamilton, 1982; Cooper \& Edgett, 1999; Danneels \& Kleinschmidt, 200I; Kleinschmidt \& Cooper, 1991; Olson et al., 1995). New-to-the-firm products are those used by the firm for the first time and they are often imitations of competitors' successful product which are already offered in the market (Cooper, 1994). New-to-the-market products are those that are the first of their kind in the market and they are developed by the firm itself or adopted from firms in other markets and industries (Sandvik and Sandvik, 2003). Secondly, product innovativeness can be defined as the product advantage which customer-perceived superiority as to quality, benefit, and functionality and product uniqueness/superiority (Montoya-Weiss and Calantone, 1994). Thirdly, product innovativeness refers to a product's technical newness or the changes it implies for the innovating firm or for the market it enters (Talke et al., 2009). Fourthly, product innovativeness can be referred to newness to the customer (Garcia and Calantone, 2002). The innovativeness of the product can also lead to the formation of new business unit(s), the extension of other product lines or the introduction of improvements into other product lines (Lee, 2008), intensification of riskaverse posture towards technology on new product performance (Talke, 2007).

\section{Suppliers Involvement (SI) and NPP}

Various definitions of supplier involvement in product development have been used in past studies. Handfield et al (1999) view it as the information suppliers provide and their participation in decision making. Afterwards, Wynstra et al (2003) define it as involvement of decisions and activities related to prioritising, mobilising, coordinating, timing, and informing with regards to these resources, tasks, and responsibilities. Recently, van Echtelt et al (2008) refer it as the resources (i.e., capabilities, investments, information, knowledge, ideas) that suppliers provide, the tasks they carry out and the responsibilities they assume regarding the development of a part, process or service for the benefit of a buyer's current or future product development projects.

Suppliers usually have greater expertise and knowledge regarding the specifications, parts and components which may be essential to a firm's new product development. As a result, supplier collaboration can help firms incorporate the expertise and different perspective of a supplier to improve its solutions or create new methods for product development (Bonaccorsi and Lipparine, 1994; Eisenhardt and Tabrizi, 1995). Supplier involvement also allows firms to identify potential technical problems and speed up new product development (Kessler and Chakrabatri, 1996). O'Neal (1993) revealed that two most significant features of concurrent engineering (i.e. customer focus centering on doing the right things and cycle time reduction focusing on doing them right the first time) can enhance quality and improve time to market of new product development. Hartley et al (1997) analysed product development engineers and managers in 79 assembly industry firms that early supplier involvement can reduce the overall time required to develop new products. Handfield et al (1999) studied 134 companies from 18 countries and revealed that early involvment of suppliers can improve the time to market, quality and technology innovation of new products. Balasubramanian and Baumgardner (2004) studied Unisys that early supplier involvement can improve time- to market of new product. Miotti and Sachwald 
(2003) used the French CIS-2 survey to reveal the positive effect of collaboration with suppliers on the share of innovative product turnover. Faems et al. (2005) studied Belgian manufacturing firms and found that suppliers had a positive impact on the proportion of turnover attributed to improved products. Hoegl and Wagner (2005) studied 28 product development projects and found that supplier collaboration positively relates to product quality, and adherence to development schedules. Mikkola and SkjøttLarsen (2006) studied a leading Danish hearing aid manufacturer and found that early involvement of suppliers in new product development reduces time-to-market. Nieto and Santamaría (2007) analysed Spanish manufacturing firms and found that collaboration with suppliers had positive impact on the degree of product innovativeness. Knudsen (2007) studied 2000 firms in seven Euorpean countries and found that supplier involvement had positive impact on new product innovative performance. Langerak and Hultink $(2005 ; 2008)$ analysed 233 manufacturing firms and found that supplier involvement can improve the speed of new product development. Rauniar et al (2008) studied a sample of 191 projects from the automotive industry in the United States and found that supplier involvement can reduce product design glitches, thereby reducing development time of the new product. Chien and Chen (2010) studied financial services firms in Taiwan and found that supplier involvement had significant effect on NPD success. Annique Un et al. (2010) stated that R\&D collaboration with suppliers was positively related to product innovation. Based on the above evidence, we propose that:

Hypothesis Ia: Suppliers collaboration in NPD process (SC) has a positive impact on new product quality and reliability.

Hypothesis Ib: Suppliers collaboration in NPD process (SC) has a positive impact on time to market.

Hypothesis Ic: Suppliers collaboration in NPD process (SC) has a positive impact on new product innovativeness.

\section{Customers Involvement $(\mathrm{Cl})$ and NPP}

Customer innovation has become an essential strategy for organisational survival because innovations can come from how organisations interact with customers by $(I)$ receiving the insights, ideas, thoughts, and information from customers, (2) encouraging customers to engage in improving existing products and services, and (3)

ISSN: 07I8-2724. (http://www.jotmi.org)

Journal of Technology Management \& Innovation @ Universidad Alberto Hurtado, Facultad de Economía y Negocios collecting, developing and commercialising customers' ideas rapidly (Desouza et al., 2008). Involvement of customers is important in the early stage of NPD process and it has a positive effect on customer satisfaction which can lead to better firm performance (Tan and Tracey, 2007) and new product success (Gruner and Homburg, 2000). In the late stages of new product development process, customer involvement can also increase new product success. However, in the medium stages of new product process, interaction with customers cannot yields any performance impact (Gruner and Homburg, 2000). Customer involvement in NPD can also speed up the process of adoption necessary for success (Johnson and Filippini, 2009).

Collaborating with customers (CC) is an important way for a firm to improve its product innovation performance (Gupta et al., 2000; Fritsch and Lukas, 200I; Brockhoff, 2003; Tsai, 2009). CC is significant in the early stage of the NPD process and working with customers can eliminate the likelihood of poor design in this stage of development (von Hippel et al., 1999). Besides, understanding the needs of customers may help firms gain new ideas about solutions (von Hippel et al., 1999), thereby increasing the chances of new product development and success. Thus, CC may lead to product innovation advantages (Souder et al., 1997; Li and Calantone, 1998) and it has a positive impact on product innovation performance (Miotti and Sachwald, 2003; Freel, 2003; Faems et al., 2005). Cooper and Slagmulder (2004) stated that customer involvement can improve the quality and reliability of the new product developed. Singh et al (2007) used a questionnaire-based survey and interpretive structural modelling (ISM) approach in their study and found that customer involvement can improve product quality and reduce development time. Rauniar et al (2008) studied a sample of 191 projects from the automotive industry in the United States and found that customer involvement can reduce product design glitches, thereby reducing development time of the new product. Chien and Chen (2010) studied financial services firms in Taiwan and found that customer involvement had significant effect on NPD success.

However, customer involvement has no influence or negative influence on the new product performance under certain circumstances. Asking customers for solutions tends to undermine the innovation process because most customers have a very limited frame of reference. 
Customers only know what they have experienced and they cannot imagine what they don't know about emergent technologies, new materials, and the like (Ulwick, 2002). In addition, Annique Un et al. (2010) state that R\&D collaborations with customers do not appear to affect product innovation. Bonner $(2010)$ also states that customer interactivity is positively related to customer information quality when developing highly innovative products, but not when developing modifications or extensions of existing products. Fang (2008) indicates that customer participation has a negative influence on innovativeness when downstream customer network connectivity is high but a positive effect when it is low. In contrast, customer participation has a positive effect on speed to market when downstream customer network connectivity is high and no significant effect when it is low.
Feiereisen et al. (2008) state that $40 \%$ to $90 \%$ of new products fail due to consumers' lack of understanding of product features and benefits.

Based on the above evidence, we propose that:

Hypothesis 2a: Customer collaboration in NPD process (CC) has a positive impact on new product quality and reliability.

Hypothesis 2b: Customer collaboration in NPD process (CC) has a positive impact on time to market.

Hypothesis 2c: Customer collaboration in NPD process (CC) has a positive impact on new product innovativeness.

A conceptual model covering the six hypotheses is proposed as shown in figure $I$.

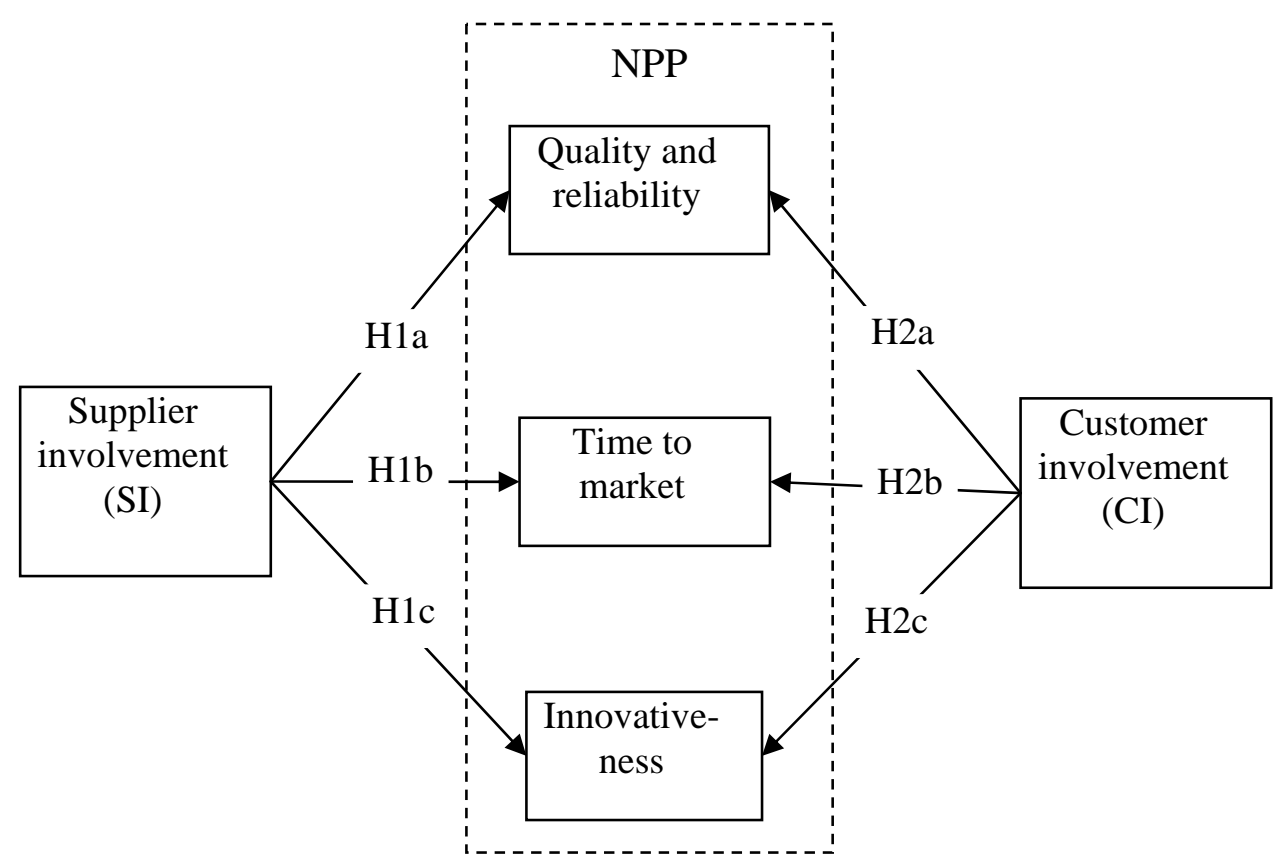

Figure I. The conceptual model showing the six hypotheses among $\mathrm{SI}, \mathrm{Cl}$ and NPP

\section{Empirical Data}

The research firstly proposed seven hypotheses relating among supplier integration and collaboration, customer integration and collaboration, new product development activities and performance. It then tested the hypotheses based on the data from the fourth round of International Manufacturing Strategy Survey (IMSS) in 2005. IMSS is an international research network consisting of more than 20 countries and over 600 companies around the world. The project aims to investigate manufacturing priorities, practices and performance of world manufacturing companies. The participant companies are in the metal products, machinery and equipment industry, i.e. ISIC 38 segment.

The research reported in this paper is based on the data from the fourth round of IMSS survey in 2005. Phone contact was first conducted in most of the participating countries to affirm the respondent companies. The 
questionnaires were forwarded to Director of manufacturing or operations or equivalent persons in respondent companies via mailing, fax or on-site interview. In countries where English is not prevailing, the questionnaire was translated into local native languages by operations management researchers. Participating countries sent their data to the coordinator who forwarded the final database to all participants. For this study, sample firms are from 2 I countries. The total sample size is 660 . The sample profiles for 21 participating countries are presented in Table I.
The IMSS questionnaire was developed by a team of experts in manufacturing strategy. It covers manufacturing strategy, practices, performance as well as market situation. Supply chain integration, customer integration and new product performance are also covered. Among other, $\mathrm{SI}, \mathrm{Cl}$ and NPP performance are all measure by I-5 scales. They measure the changes of $\mathrm{SI}$ and $\mathrm{Cl}$ in the past three years. The questions are listed in Table 2.

\begin{tabular}{l|c|c|c}
\hline \multicolumn{1}{c|}{ Countries } & Frequency & Percent & Cumulative Percent \\
\hline Argentina & 44 & 6.7 & 6.7 \\
Australia & 14 & 2.1 & 8.8 \\
Belgium & 32 & 4.8 & 13.6 \\
Brazil & 16 & 2.4 & 16.1 \\
Canada & 25 & 3.8 & 19.8 \\
China & 38 & 5.8 & 25.6 \\
Denmark & 36 & 5.5 & 31.1 \\
Germany & 18 & 2.7 & 33.8 \\
Greece & 13 & 2.0 & 35.8 \\
Hungary & 54 & 8.2 & 43.9 \\
Ireland & 15 & 2.3 & 46.2 \\
Israel & 20 & 3.0 & 49.2 \\
Italy & 45 & 6.8 & 56.1 \\
New Zealand & 30 & 4.5 & 60.6 \\
Norway & 17 & 2.6 & 63.2 \\
Portugal & 10 & 1.5 & 64.7 \\
Sweden & 82 & 12.4 & 77.1 \\
Netherlands & 63 & 9.5 & 86.7 \\
Turkey & 35 & 5.3 & 92.0 \\
UK & 17 & 2.6 & 94.5 \\
USA & 36 & 5.5 & 100.0 \\
Total & 660 & 100.0 & \\
\hline
\end{tabular}

Table I. Sample profiles by Countries 


\begin{tabular}{|l|lllll|}
\hline \multicolumn{1}{|c|}{ Questions } & \multicolumn{5}{c|}{ Measurement } \\
\hline Improvement of NPP in the past three years: & None & Some & Great \\
\hline -New Product quality and reliability & $\mathrm{I}$ & 2 & 3 & 4 & 5 \\
\hline -Time to market & $\mathrm{I}$ & 2 & 3 & 4 & 5 \\
\hline -Product innovativeness & $\mathrm{I}$ & 2 & 3 & 4 & 5 \\
\hline $\begin{array}{l}\text { Implementation of suppliers and customers involvement in } \\
\text { NPD in past three years: }\end{array}$ & None & Some & Great \\
\hline -Supplier involvement & & & & \\
\hline -Customer involvement & $\mathrm{I}$ & 2 & 3 & 4 & 5 \\
\hline & $\mathrm{I}$ & 2 & 3 & 4 & 5 \\
\hline & & & & \\
\hline
\end{tabular}

Table 2. Questions about $\mathrm{SI}, \mathrm{Cl}$ and NPP

\section{Results}

The basic statistics of the five variables are summarised in table 3. It can show that in the past three years, companies made improvement in three of the dimensions of NPP.
Also companies implemented $\mathrm{SI}$ and $\mathrm{Cl}$ as well. However, a $t$-test shows that there is significant difference between the means of $\mathrm{SI}$ and $\mathrm{Cl}(\mathrm{t}=10.23, \mathrm{p}<0.00 \mathrm{I})$. It implies that companies pay more attention to $\mathrm{Cl}($ mean $=3.47)$ than $\mathrm{SI}$ $($ mean $=2.92)$.

\begin{tabular}{|c|c|c|c|c|c|}
\hline & $\mathrm{N}$ & Min & Max & Mean & Std. Deviation \\
\hline Quality and reliability & 692 & $\mathrm{I}$ & 5 & 3.07 & $.85 \mathrm{I}$ \\
\hline Time to market & 679 & $\mathrm{I}$ & 5 & 2.83 & .888 \\
\hline Product innovativeness & 682 & $\mathrm{I}$ & 5 & 2.89 & .885 \\
\hline Supplier involvement & 683 & $\mathrm{I}$ & 5 & 2.92 & $\mathrm{I} .106$ \\
\hline Customer involvement & 682 & $\mathrm{I}$ & 5 & 3.47 & $\mathrm{I} .096$ \\
\hline
\end{tabular}

Table 3. Basic statistics of NPP, SI and Cl

\begin{tabular}{|l|c|c|}
\hline New product performance (NPP) & Supplier involvement & Customer involvement \\
\hline -New Product quality and reliability & $0.17^{* *}$ & $0.13^{* *}$ \\
\hline -Time to market & $0.16^{* *}$ & $0.10^{*}$ \\
\hline -Product innovativeness & $0.14^{* *}$ & \\
\hline
\end{tabular}

Notes: $p^{*}<0.05, p^{* *}<0.00$ I (all one-tailed tests)

Table 4. Simple correlation analysis

Simple correlation is conducted first as shown in table 4. Except for the relationship between $\mathrm{Cl}$ and time to market, all other relationships are significant. However, Structural Equation Modeling (SEM) produces different result for the impact of $\mathrm{Cl}$. The testing results are shown in figure 2. The fitness indexes are $C M I N / D F=1.754<3$, $\mathrm{NFI}=0.988, \mathrm{RFI}=0.9 \mathrm{l} 4 \mathrm{IFI}=0.995, \mathrm{TLI}=0.96 \mathrm{I}, \mathrm{CFI}=0.995$, RMSEA $=0.033$. The model shows that $\mathrm{HIa}, \mathrm{HIb}, \mathrm{HIc}$, and $\mathrm{H}_{2} \mathrm{a}$ are supported but $\mathrm{H}_{2}$ and $\mathrm{H}_{2} \mathrm{c}$ are not supported. It is also observed that the correlation between $\mathrm{SI}$ and NPP is stronger (0.14 to 0.16 vs 0.08$)$ and more significant $(P<0.00$ I vs. $P<0.01)$ than those between $\mathrm{Cl}$ and NPP. The implications of the results will be discussed below. 


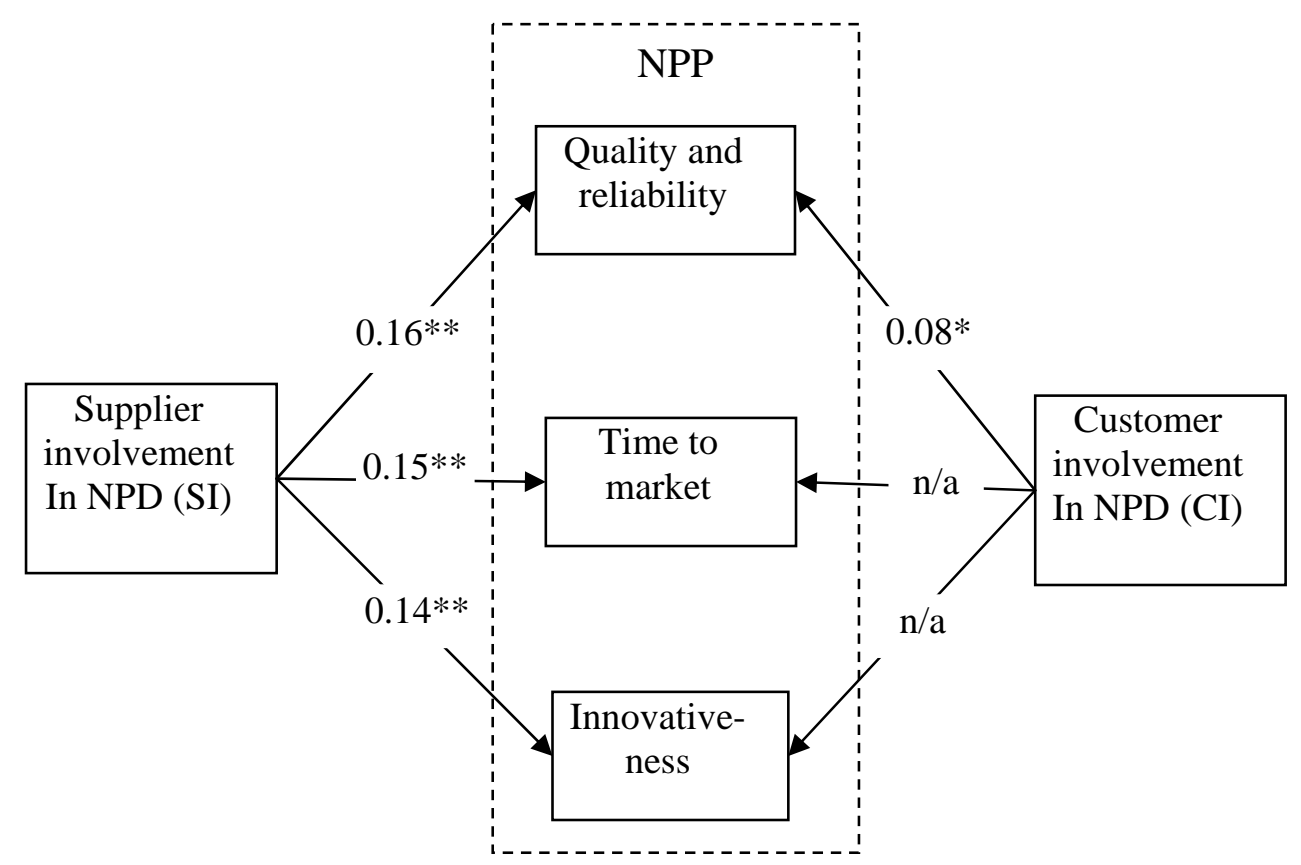

Figure 2. The result of hypotheses testing (**: $p<0.00 I ; *: p<0.05)$

\section{Discussions}

The research reveals that there are differences in the impact of $\mathrm{SI}$ and $\mathrm{Cl}$ on NPP. Consistent with previous research, this research supports the hypotheses that SI positively influences NPP. SI positively influences all the three dimensions of NPP, including new product quality and reliability, product innovativeness and the time to market. However, contradict to previous research, $\mathrm{Cl}$ influences only on the quality and reliability. Hypotheses on the impact of $\mathrm{Cl}$ on time to market and innovativeness are not supported. The different result may be explained from methodological perspective as well as customer expectations.

First, different data analysis method may lead to different results. Previous research on the relationship between $\mathrm{Cl}$ and NPP covered only SI and was based on simple correlation. Simple correlation method treats all variables as independent and, as a result, ignores the simultaneous impact of $\mathrm{SI}$ and $\mathrm{Cl}$. SEM covers all the variables and the potential relationships among the variables. This suggests that if the variables may have interrelation among each other, a conceptual model should be proved and tested by Structural Equation Modeling (SEM).
Second, the customer, especially end users of new product, may not have sufficient technical knowledge to help manufacturers improve the production process in order to shorten the time to market and develop innovative products. This finding is also supported by Ulwick (2002), Fang (2008) and Annique Un et al. (2010). Conversely, customers only concern the quality and reliability products. For industrial users, a company may not want their customer to know too much of their technical details for confidential reasons. This implies that future research should separate customers into different types such as end users and industrial users. Customer involvement may drag the NPD process longer since they always ask too much from the company.

This research has a few implications for research design. First, $\mathrm{SI}$ and $\mathrm{Cl}$ are both studies in this research. Previous research mostly looks at either $\mathrm{SI}$ or $\mathrm{Cl}$. However, $\mathrm{SI}$ and $\mathrm{Cl}$ affect NPP simultaneously and therefore; both should be considered in such research. Collaboration theory suggests that companies need to collaborate with suppliers in SCM field or customer from marketing perspective. Both streams of research hold a two-party perspective about collaboration in NPD. This research finds that both $\mathrm{SI}$ and $\mathrm{Cl}$ are important and suggests a three-party perspective, including the company, the suppliers and the customers. This suggests the shift from a two-party 
perspective to a three-party perspective in NPD. The three-party perspective implies that a new mechanism is needed to coordinate both the suppliers and the customers at the same time.

Another implication is that NPP is not a single dimension variable. NPP covers at least three dimensions like quality, reliability, innovativeness and time to market. The separation of the three dimensions help people get into the insight of impact of $\mathrm{SI}$ and $\mathrm{Cl}$. It is not enough to find out whether $\mathrm{SI}$ and $\mathrm{Cl}$ influence on performance. It is more meaningful to find out what $\mathrm{SI}$ and $\mathrm{Cl}$ influence. This research suggests a multidimensionality of new product performance.

There are also a few practical implications for managers. The research suggests that both $\mathrm{SI}$ and $\mathrm{Cl}$ should be implemented in new product development process. Although more research has been conducted on $\mathrm{SI}$ recently, it seems that more efforts in both academic and practical fields are needed to enhance SI in NPD. There are several practical issues to explore for managers and researchers. For example, shall a company start with $\mathrm{SI}$ first or $\mathrm{Cl}$ first? Is there any interrelationship between $\mathrm{SI}$ and $\mathrm{Cl}$ ? Will supplier and customer work together? If so, who will coordinate with $\mathrm{SI}$ and $\mathrm{Cl}$ which are in different functional departments? Will electronic system influence the $\mathrm{SI}$ and $\mathrm{Cl}$ ? If so, how to implement ERP (Enterprise Resources Planning) to enhance $\mathrm{SI}$ and $\mathrm{Cl}$ ?

There are also other implications for future research. Factor influencing $\mathrm{SI}$ and $\mathrm{Cl}$ have attracted attention of researchers. It will continue to be an interesting and attractive to investigate factors enhancing $\mathrm{SI}$ and $\mathrm{Cl}$. For example, commitment and trust are often cited in the field. However, are there any differences between the factors which influence $\mathrm{SI}$ and $\mathrm{Cl}$ ? If there are differences, how can a company play the different roles along the supply chain to enhance $\mathrm{SI}$ and $\mathrm{Cl}$ ? Another stream of research related to $\mathrm{SI}$ and $\mathrm{Cl}$ is the conditions or factors that mediate $\mathrm{SI}$ and $\mathrm{Cl}$. For example, research reveals that market stability will mediate SI (Jayalarm, 2008). Future research can be conducted to explore the conditions for both $\mathrm{SI}$ and $\mathrm{Cl}$.

\section{Conclusion}

This paper investigates the simultaneous impact of SI and $\mathrm{Cl}$ on NPP. There are two new points in this research. The first is the research design from a two-party perspective to a three-party perspective. The three-party perspectives will have an impact on the research on $\mathrm{SI}, \mathrm{Cl}$ and NPP in the future. Another contribution is the elaboration of NPP from one construct of NPP to three dimensions. The three-party perspective and multidimension of NPP will greatly enrich the research on NPD in the future.

The limitation of this research lies in the measure. All variables are measured by simple I-5 scales. Future research can use well designed constructs with more items. Additionally, comparative studies can be conducted to probe into the difference in $\mathrm{SI}$ and $\mathrm{Cl}$ impact on new product performance in different countries or industries.

\section{Acknowledgement}

The research reported in this paper was supported by a General Research Fund (CityU 148808) offered by the Hong Kong SAR Government.

\section{References}

ANNIQUE UN, C., Cuervo-Cazurra, A., Asakawa, K. (2010). R\&D Collaborations and Product Innovation. Journal of Product Innovation Management 27, 673-689.

BALASUBRAMANIAN, R., Baumgardner, S. (2004). Good supplier management aids new product launch. Quality Progress 37(6), 49-57.

BONACCORSI, A., Lipparini, A. (1994). Strategic Partnerships in New Product Development:An Italian Case Study. Journal of Product Innovation Management II(2), I34145.

BONNER, J.M. (2010). Customer interactivity and new product performance: Moderating effects of product newness and product embeddedness. Industrial Marketing Management 39, 485-492.

BOOZ, Allen \& Hamilton. (1982). New product management for the 1980's. Booz, Allen \& Hamilton, New York.

BROCKHOFF, K. (2003). Customers' perspectives of involvement in new product development. International Journal of Technology Management 26(5), 464-48I. 
BÛYÛKÔZKAN, G., Dereli, L., Baykasoglu, A. (2004). A survey on the methods and tools of concurrent new product development and agile manufacturing. Journal of Intelligent Manufacturing I5, 73I-75I.

CHIEN, S.H., Chen, J.J. (20I0). Supplier involvement and customer involvement effect on new product development success in the financial service industry. The Service Industries Journal 30(2), I85-20I.

CHIU, Y. C, Chen, B., Shyu, J.Z., Tzeng, G..H. (2006). An evaluation model of new product launch strategy. Technovation 26(I I), 1244-1252.

COOPER, R., Slagmulder, R. (2004). Interorganizational cost management and relational context. Accounting, Organizations and Society 29, I-26.

COOPER, R. G. (1994). New products: The factors that drive success. International Marketing Review II (I), 60-67.

COOPER, R. G., Edgett, S. (1999). Product development for the service sector. Lessons from market leaders. Perseus Books, Cambridge, MA.

CORALLO, A., Laubacher, R., Margherita, A., Turrisi, G. (2009). Enhancing product development through knowledge-based engineering (KBE) - A case study in the aerospace industry. Journal of Manufacturing Technology Management 20(8), 1070-1083.

DANNEELS, E., Kleinschmidt, E. J. (200I). Product innovativeness from the firm's perspective: Its dimensions and their relation with project selection and performance. Journal of Product Innovation Management I8(6), 357- 373.

DE MEYER, A., Van Hooland, B. (1990). The contribution of manufacturing to shortening design cycle times. R\&D Management 20(3), 229-239.

DESOUZA, K.C., Awazu, Y., Jha, S., Dombrowski, C., Papagari, S., Baloh, P., Kim, J.Y. (2008). Customer-driven innovation. Research Technology Management 5I(3), 35-44.

DOSTALER, I. (2010). Avoiding rework in product design: evidence from the aerospace industry. International Journal of Quality \& Reliability Management 27(I), 5-26.
EISENHARDT, K.M., Tabrizi, B.N. (1995). Accelerating adaptive processes: product innovation in the global computer industry. Administrative Science Quarterly 40(I), 84-110.

FABBE-COSTES, N., Jahre, M. (2008). Supply chain integration and performance: a review of the evidence, The International Journal of Logistics Management 19(2), I30-I54.

FAEMS, D., Van Looy, B., Debackere, K. (2005). Interorganizational collaboration and innovation: toward a portfolio approach. Journal of Product Innovation Management 22(3), 238-250.

FANG, E. (2008). Customer Participation and the TradeOff Between New Product Innovativeness and Speed to Market. Journal of Marketing 72, 90-104.

FEIEREISEN, S., Wong, V., Broderick, A. J. (2008). Analogies and Mental Simulations in Learning for Really New Products: The Role of Visual Attention. Journal of Product Innovation Management 25, 593-607.

FREEL, M.S. (2003). Sectoral patterns of small firm innovation, networking and proximity. Research Policy 32(4), 75I-770.

FRITSCH, M., Lukas, R. (200I). Who cooperates on R\&D? Research Policy 30(2), 297-3I2.

FROHLICH, M.T., Westbrook, R. (200I). Arcs of integration: an international study of supply chain strategies. Journal of Operations Management 19, 185-200.

GARCIA, R., Calantone, R. (2002). A critical look at technological innovation typology and innovativeness terminology: a literature review. The Journal of Product Innovation Management 19, I I0—I32.

GARCIA, N., Sanzo, M., Trespalacios, J. (2008). New product internal performance and market performance: Evidence from Spanish firms regarding the role of trust, interfunctional integration, and innovation type. Technovation 28, 7/3-725.

GRIFFIN, A. (1993). Metrics for Measuring Product Development Cycle Time. Journal of Product Innovation Management 10, II2-125. 
GRUNER, K., Homburg, C. (2000). Does Customer Interaction Enhance New Product Success? Journal of Business Research 49, I-I4.

GUPTA, A., Wilemon, D., Atuahene-Gima, K. (2000). Excelling in R\&D. Research Technology Management 43(3), 52-59.

HANDFIELD, R.B., Ragatz, G.L., Petersen, K.J., Monczka, R.M. (1999). Involving suppliers in new product development. California Management Review 42(I), 59-82.

HARTLEY, J.L., Meredith, J.R., McCutcheon, D., Kamath, R.R. (1997). Suppliers' contributions to product development: an exploratory survey. IEEE Transaction on Engineering Management 44(3), 258-267.

HARTLEY, J.L., Zirger, B.J., Kamath, R.R. (1997). Managing the buyer-supplier interface for on-time performance in product development. Journal of Operations Management 15, $57-70$.

HOEGL, M., Wagner, S. (2005). Buyer-Supplier Collaboration in Product Development Projects. Journal of Management 3I (4), 530-548.

HSU, C., Tan, K., Kannan, V., Keong, L, G. (2009). Supply chain management practices as a mediator of the relationship between operations capability and firm performance. International Journal of Production Research 47(3), 835-855.

ITTNER, C.D., Larcker, D.F. (1997). Product development cycle time and organizational performance. Journal of Marketing Research 34, 522-534.

JAYARAM, J. (2008). Supplier involvement in new product development projects: dimensionality and contingency effects. International Journal of Production Research 46(I3), 3717-3735.

JOHNSON, W., Filippini, R. (2009). Internal vs. external collaboration:What works. Research Technology Management 52(3), 15- 17.

KESSLER, E., Chakrabarti, A. (1996). Innovation Speed: A Conceptual Model of Context, Antecedents, and Outcomes. Academy of Management Review 2I(4), II431191.
KLEINSCHMIDT, E. J., Cooper, R. G. (1991). Impact of product innovativeness on performance. Journal of Product Innovation Management 8(4), 240- 25I.

KNUDSEN, M.P. (2007). The Relative Importance of Interfirm Relationships and Knowledge Transfer for New Product Development Success. Journal of Product innovation Management 24, II7-138.

LANGERAK, F., Hultink, E.J. (2005). The Impact of New Product Development Acceleration Approaches on Speed and Profitability: Lessons for Pioneers and Fast Followers. IEEE Transactions on Engineering Management 52(I), 30-42.

LANGERAK, F., Hultink, E.J. (2008). The effect of new product development acceleration approaches on development speed: A case study. Journal of Engineering Technology management 25, I57-167.

LANGERAK, F., Hultink, E., Robben, H. (2004). The impact of market orientation, product advantage,and launch proficiency on new product performance and organizational performance. Journal of Product Innovation Management 2I (I), 79-94.

LEE, L.T.S. (2008). The effects of team reflexivity and innovativeness on new product development performance. Industrial Management \& Data Systems 108(4), 548-569.

LI, T., Calantone, R.J. (1998). The impact of market knowledge competence on new product advantage: conceptualization and empirical evidence. Journal of Marketing 62(4), I3-29.

MIKKOLA, J.H., Skjøtt-Larsen, T. (2006). Platform management - Implication for new product development and supply chain Management. European Business Review I8(3), 2|4-230.

MILLSON, M.R., Wilemon, D. (2006). Driving new product success in the electrical equipment manufacturing industry. Technovation 26(II), 1268-1286.

MIOTTI, L., Sachwald, F. (2003). Co-operative R\&D: why, and with whom? An integrated framework of analysis. Research Policy 32(8), I48I-I499. 
MOLINA-CASTILLO, F., Munuera-Alemán, J. (2009a). The joint impact of quality and innovativeness on short-term new product performance. Industrial Marketing Management 38, 984-993.

MOLINA-CASTILLO, F.., Munuera-Alema'n, J. (2009b). New product performance indicators: Time horizon and importance attributed by managers. Technovation 29, 7/4724.

MONTOYA-WEISS, M., Calantone, R.J. (1994). Determinants of New Product Performance: A Review and Meta Analysis. Journal of Product Innovation Management II (5), 397-4I 7.

NIETO, M.J., Santamaría, L. (2007). The importance of diverse collaborative networks for the novelty of product innovation. Technovation 27(3), 367-377.

O'NEAL, C. (1993). Concurrent engineering with early supplier involvement: A cross-functional challenger. International Journal of Purchasing and Materials Management 29(2), 2-9.

OLSON, E. M., Walker, O. C., Ruekert, R. W. (1995). Organizing for effective new product development: The moderating role of product innovativeness. Journal of Marketing 59, 48- 62.

PAUWELS, K., Silva-Risso, J., Srinivasan, S., Hanssens, D. (2004). New products, sales promotions, and firm value; the case of the automobile industry. Journal of Marketing 68(4), 142-156.

PETERSEN, K., Handfield, R., Ragatz, G. (2005). Supplier integration into new product development:coordinating product, process and supply chain design. Journal of Operations Management 23, 37I-388.

POWER, D. (2005). Supply chain management integration and implementation: a literature review. Supply Chain Management: an International Journal I0(4), 252-263.

RAUNIAR, R., Doll, W., Rawski, G., Hong, P. (2008). Shared knowledge and product design glitches in integrated product development. International Journal of Production Economics II4, 723-736.
ROSENZWEIG, E., Roth, A., Dean, James W. Jr. (2003). The influence of an integration strategy on competitive capabilities and business performance: an exploratory study of consumer products manufacturers. Journal of Operations Management 2I(4), 437-456.

SANDVIK, I.K., Sandvik, K. (2003). The impact of market orientation on product innovativeness and business performance. International Journal of Research in Marketing 20(4), 355-376.

SINGH, R.K., Garg, S.K., Deshmukh, S.G., Kumar, M. (2007). Modelling of critical success factors for implementation of AMTs. Journal of Modelling in Management 2(3), 232-250.

SOUDER, W.E., Buisson, D., Garrett, T. (1997). Success through customer-driven new product development: a comparison of US and New Zealand small entrepreneurial high technology firms. Journal of Product Innovation Management 14(5), 459-472.

STALK, G., Hout, T.M. (1990). Competing against time. The Free Press, New York.

SWINK, M., Narasimhan, R., Wang, C. (2007). Managing beyond the factory walls: effects of four types of strategic integration on manufacturing plant performance. Journal of Operations Management 25, I48-164.

TALKE, K. (2007). Corporate mindset of innovating firms: influences on new product performance. Journal of Engineering and Technology Management 24(I), 76-91.

TALKE, K., Salomo, S., Wieringa, J.E., Lutz, A. (2009). What about Design Newness? Investigating the Relevance of a Neglected Dimension of Product Innovativeness? Journal of Product Innovation Management 26, 60I-6I5.

TAN, C., Tracey, M. (2007). Collaborative new product development environments: Implications for supply chain management. Journal of Supply Chain Management 43(15), $2-15$.

TSAI, K. (2009). Collaborative networks and product innovation performance: Toward a contingency perspective. Research Policy 38, 765-778. 
ULWICK, A.W. (2002). Turn customer input into innovation. Harvard Business Review 9I - 97.

VACHON, S., Klassen, R,D. (2006). Extending green practices across the supply chain: the impact of upstream and downstream integration. International Journal of Production \& Operations management 26(7), 795-82I.

VAN ECHTELT, F, E.A., Wynstra, F, van Weele, A. J., Duysters, G. (2008). Managing supplier involvement in new product development: A Multiple-Case Study. The Journal of Product Innovation Management 25, 180-20I.

VON HIPPEL, E.A., Thomke, S., Sonnack, M. (1999). Creating breakthroughs at 3M. Harvard Business Review 77(5), 47-57.

WYNSTRA, J.Y. F, Weggeman, M., Van Weele, A. J. (2003). Exploring Purchasing Integration in Product Development. Industrial Marketing Management 32(I), 6983.

ZAILANI, S., Rajagopal, P. (2005). Supply chain integration and performance: US versus East Asian companies. Supply Chain Management: an International Journal I0(5), 379-393. 